Tae-Ju Oh

Stephen J. Meraw

Eun-Ju Lee

William V. Giannobile

Hom-Lay Wang

\section{Authors' affiliations:}

Tae-Ju Oh, Stephen J. Meraw, William V.

Giannobile, Hom-Lay Wang, Department of

Periodontics/Prevention/Geriatrics, University

of Michigan School of Dentistry, Ann Arbor,

MI, USA

Eun-Ju Lee, Private practice, Seoul, Korea

\section{Correspondence to:}

Hom-Lay Wang, DDS., MSD.

Diplomate, American Board of Periodontology

Associate Professor and Director of Graduate

Periodontics

Department of Periodontics/Prevention/

Geriatrics

University of Michigan School of Dentistry

IOI I North University Avenue

Ann Arbor, Michigan 48109-I078

USA

Tel: + I 7347633383

Fax: + I 7349360374

e-mail: homlay@umich.edu
Date:

Accepted 6 December 2001

To cite this article:

Oh TJ, Meraw SJ, Lee EJ, Giannobile WV, Wang HL.

Comparative analysis of collagen membranes for

the treatment of implant dehiscence defects

Clin. Oral Impl. Res, I4, 2003; 80-90

Copyright (C) Blackwell Munksgaard 2003

ISSN 0905-7I6I

\title{
Comparative analysis of collagen membranes for the treatment of implant dehiscence defects
}

Key words: barrier membranes; bioabsorbable; collagen membrane; dental implants; guided bone regeneration; implant dehiscence defects; membrane exposure.

\begin{abstract}
Guided bone regeneration (GBR) evolved from the concept of guided tissue regeneration (GTR) and has been used for reconstructing sites with bone deficiencies associated with dental implants. For GBR, the use of absorbable collagen membranes has been increasing, but, at present, scientific information on the use of collagen membranes for GBR is limited. This study was aimed to clinically and histomorphometrically compare two collagen membranes, Bio-Gide ${ }^{\circledR}$ and BioMend Extend ${ }^{\mathrm{TM}}$, for the treatment of implant dehiscence defects in eight mongrel dogs. Implant dehiscence defects were surgically created in edentulous ridges, followed by the placement of three endosseous implants bilaterally in the mandible. Each implant dehiscence defect was randomly assigned to one of three treatment groups: (1) control (no membrane), (2) porcine dermis collagen barrier (Bio-Gide) or (3) bovine tendon collagen barrier (BioMend Extend). Dogs were sacrificed at 4 and 16 weeks (four dogs each) after treatment. Histomorphometric analysis included percentage linear bone fill (LF), new bone-to-implant contact (BIC) and area of new bone fill (BF). The results of the study revealed no significant differences among groups for any parameter at 4 weeks. However, at 16 weeks, more LF, BIC, and BF were noted in the membrane-treated groups than controls. BioMend Extend-treated defects demonstrated significantly greater BIC than control $(P<0.05)$ at this time point. BIC at 16 weeks was significantly greater than 4week BIC $(P<0.05)$. Membrane exposure occurred in 9 out of 15 sites examined, resulting in significantly less LF and BIC than the sites without membrane exposure $(P<0.05)$. The results of this study indicate that: (1) GBR treatment with collagen membranes may significantly enhance bone regeneration, manifested at late stage (16 weeks) of healing; and (2) space maintenance and membrane coverage were the two most important factors affecting GBR using bioabsorbable collagen membranes.
\end{abstract}

The demand for replacing missing teeth with dental implants has increased dramatically; however, it has often been limited by the amount of available bone. Guided bone regeneration (GBR) was introduced to correct this deficiency and has shown promising results. The concept of GBR evolved from guided tissue regeneration (GTR) and is used to compartmentalize neosteogenesis using barrier mem- branes by protecting the blood clot, creating space, and excluding soft tissue cell proliferation (Boyne I969; Dahlin et al. I988; Dahlin et al. I99I; Linde et al. I993a).

Fugazzotto et al. (I997) assessed I503 GBR-treated implant sites with clinical reentries and reported an overall success rate of $97.0 \%$ for the treatment of dehisced or fenestrated implants placed in immediate 
extraction sockets. Hermann \& Buser (I996) discussed five surgical factors that are required to achieve predictable results with GBR procedures:

I use of an appropriate membrane;

2 achievement of primary soft tissue healing;

3 creation and maintenance of a membrane-protected space,

4 close adaptation and stabilization of the membrane to the surrounding bone;

5 sufficiently long healing period.

While GTR procedures are associated with natural teeth, GBR is mainly involved in implant dentistry where inadequate bone is the concern. Adequate bone volume is one of the requirements for the successful installation and osseointegration of an endosseous implant (Lekholm \& Zarb I985). GBR is often used in extraction sockets, deficient ridges, and dehiscence and fenestration defects, associated with dental implants (Mellonig \& Nevins I995).

Prerequisites for an ideal barrier membrane include biocompatibility, cell occlusivity, tissue integration, space-making effect, and clinical manageability. The ePTFE membrane, nonabsorbable, appears to fulfill these needs. However, it has been recognized that the use of the nonabsorbable membrane has been limited by the necessity of second surgery for membrane removal and its high membrane exposure rate (Gotfredsen et al. I993; Becker et al. I994; Simion et al. I994a), potentially resulting in patient discomfort, increased cost, postsurgical infection, and possibly suboptimal bone regeneration. Bioabsorbable membranes were then developed and have demonstrated comparable results to the e-PTFE membrane in numerous experimental animal studies (Sandberg et al. I993; Sevor et al. I993; Zellin et al. I995) and case reports (Balshi et al. I99I; Sevor \& Meffert I992; Lundgren et al. I994; Mayfield et al. I997). Currently tested and used absorbable membranes are made of collagen or of polyglycolic acid, polylactic acid, or copolymers (Hutmacher et al. I996; Wang \& MacNeil I998).

Collagen membranes are mechanically malleable, adaptable, and easy to manipulate, which may be beneficial in clinical application. Other advantageous properties of collagen include hemostatic function, facil- itating early wound stabilization, semipermeability, allowing nutrient passage, natural enzymatic degradation, and chemotactic ability to attract fibroblasts (Postlethwaite et al. I978). The safety and efficacy of collagen membranes have been proven in the field of GTR (Blumenthal I988; Wang et al. I994; Crigger et al. I996; Yukna \& Yukna I996) as well as in GBR (Sevor et al. I993; Zitzmann et al. I997; Hürzeler et al. I998). Hürzeler et al. (I998) evaluated a bioabsorbable membrane, Bio-Gide ${ }^{\circledR}$ /Osteohealth, Shirley, NY, USA), used for GBR around exposed implant threads in monkeys, and showed histologically comparable effects of the membrane to the e-PTFE membrane when used with Bio-Oss ${ }^{\circledR}$ /Osteohealth, Shirley, NY, USA) bone graft materials.

Buccal dehiscence defects are one of the most commonly encountered problems in implant dentistry. There have been a number of experimental and clinical studies on GBR using this type of defect (Zablotsky et al. I99I; Becker et al. I992; Sevor et al. I993; Zitzmann et al. I997; Hämmerle et al. I998; Peleg et al. I999). Compared to the lingual bone, especially in the maxillary anterior region, buccal bony housing is thin; thus, bone resorption after tooth extraction in buccal areas is faster and far more prevalent. According to Lam (I960), the abundant bone volume does not remain more than a few years following tooth loss, and the original crestal width is reduced by at least $30 \%$ within 2 years after extraction. To overcome the difficulty of space creation around buccal dehiscence defects, several treatment approaches, such as membranes with space fillers or titanium-reinforced e-PTFE membranes, are often utilized in GBR (Simion et al. I994b; Fritz et al. 2000)

Longevity and space-maintaining ability are the most challenging concerns regarding absorbable membranes in GBR procedures. Studies have demonstrated that early removal of membranes resulted in reduced bone formation and incomplete bone fill (Lekholm et al. I993; Becker et al. I994). Several clinicians have advocated that membranes used for GBR should last longer, ranging 3-9months, than GTR membranes. Bio-Gide, a collagen membrane claimed to last 4-6 months, was developed to fulfill this goal. Several other companies have also developed other longlasting membranes, including BioMend Extend $^{\mathrm{TM}}$ (Sulzer Calcitek, Carlsbad, CA,
USA) and Ossix TM (Implant Innovations, Inc., Palm Beach Gardens, FL, USA).

Bio-Gide is derived from porcine dermis and composed of type I and III collagen. It has two layers: (I) the compact layer, designed to protect soft tissue invasion; and (2) the porous layer, designed to facilitate integration of newly formed bone. BioMend Extend is a type I collagen membrane derived from bovine tendon and is highly cross-linked to prolong membrane barrier function to maximize time necessary for tissue regeneration.

There have been limited histomorphometric studies specifically on GBR using collagen membranes. The present study was aimed to compare, clinically and histomorphometrically, the effects of two different collagen membranes (BioGide and BioMend Extend) on GBR in surgically created buccal implant dehiscence defects in dogs.

\section{Material and methods}

Eight systemically healthy male mongrel dogs, aged from I to 2 years and weighing $24-43 \mathrm{~kg}$, were used in this study. The dogs had full, well-aligned dentitions without clinical signs of destructive periodontal disease. The study was performed following approval by the University Committee on Use and Care of Animals (UCUCA) at the University of Michigan.

\section{Surgical management}

After an adaptation period of 4 weeks, each animal received full-mouth scaling and extraction of the mandibular 2nd, $3 \mathrm{rd}$, and $4^{\text {th }}$ premolars $\left(\mathrm{P}_{2}-\mathrm{P}_{4}\right)$ bilaterally under general anesthesia. After I6 weeks of healing, buccal dehiscence defects were prepared as described by Becker et al. (I992). Midcrestal incisions followed by full thickness mucoperiosteal flap elevation were performed, and the crestal bone was uniformly prepared by osteoplasty using a round bur or bone chisel. Following implant site preparation (surgery protocol by Sulzer Calcitek), buccal dehiscence defects, approximately $4 \mathrm{~mm}$ in height from the crestal bone, $3 \mathrm{~mm}$ in depth from the surface of the buccal bone, and $3 \mathrm{~mm}$ in width mesiodistally, were created with a straight fissure carbide bur. The osteotomy procedures were carried out under copious saline irrigation. The defect size was stan- 
dardized with the use of a periodontal probe. After defect creation, three titanium threaded implants SSpline $^{\mathrm{TM}}$ TWIST MTX $^{\mathrm{TM}}$, Sulzer Calcitek, Carlsbad, CA, USA), $3.75 \mathrm{~mm}$ in diameter and $8 \mathrm{~mm}$ in length, were placed in each quadrant, and three treatment modalities (Bio-Gide, BioMend Extend or control) were randomly assigned to each implant defect using a random number table (Fig. I). Block randomization was used for grouping with each quadrant as a block. The membranes were trimmed and placed over the defects to cover the implant and defect, extending 2-3 $\mathrm{mm}$ beyond the defect margin. Primary wound closure was accomplished by flap releasing and closure with 4-o Vicryl (polyglactin 9I0) suture using the simple interrupted suture technique to achieve primary intention healing.

\section{Oral hygiene and diet}

During the presurgical period, animals received three times weekly toothbrushing with a soft brush and $0.2 \%$ chlorhexidine gel. Following surgery, chlorhexidine swabbing of tissues was performed in lieu of brushing for 2 weeks. The dogs were fed a daily canine diet (LabDiet Certified Canine Diet 5007, PMI Feeds, Inc., / and filtered tap water ad libitum. For the first 3 weeks after surgery, a soft diet was used to minimize mechanical trauma to the flaps.

\section{Bone labeling}

To assess the pattern of osteogenesis and delineate the base of the original defect, three fluorochrome bone labels were used. For the 4-week biopsy group, a series of three bone labels were administrated in the following sequence (Giannobile et al. I998):

- calcein green $(8 \mathrm{mg} / \mathrm{kg}, \mathrm{IM}) 2$ days after implant placement;

- xylenol orange $(60 \mathrm{mg} / \mathrm{kg}, \mathrm{IV}) 2$ weeks after the surgery;

- tetracycline $\mathrm{HCl}$ (romg/kg, I.M.) 2 days prior to sacrifice.

For I6-week biopsy specimens, animals received a series of four bone labels:
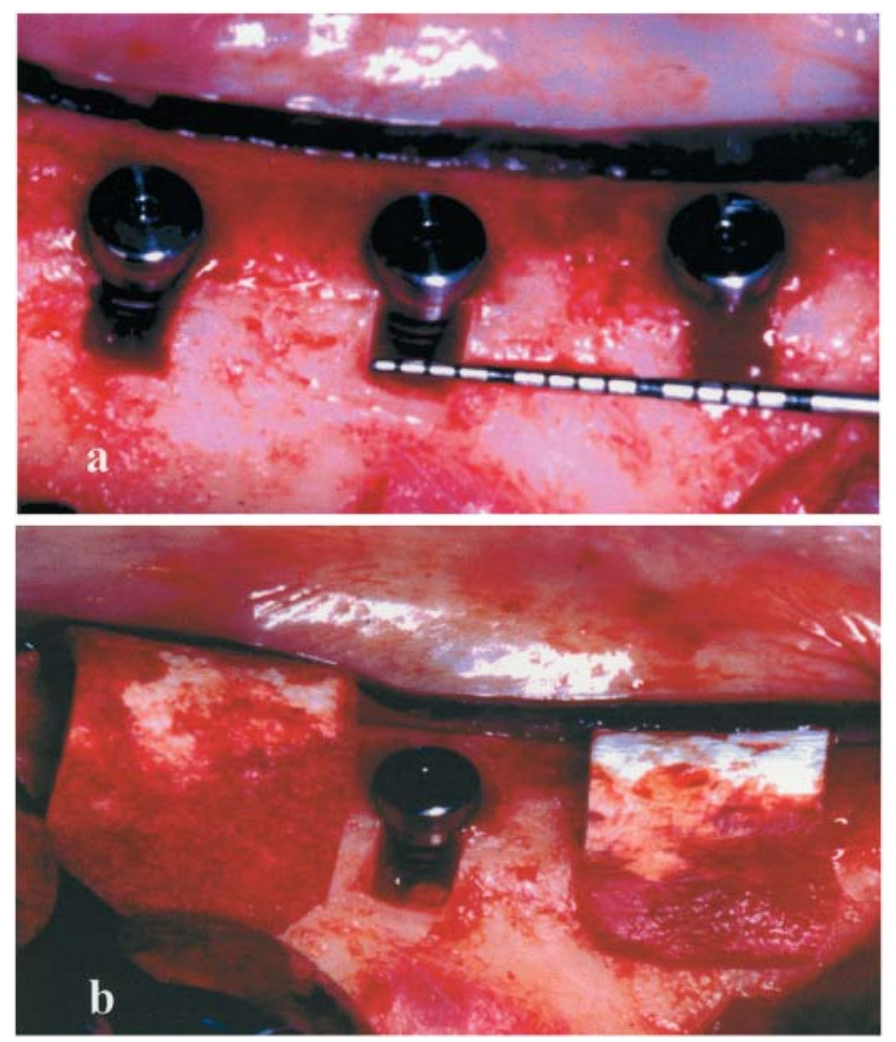

Fig. I. Defect creation, implant insertion, and membrane placement. a. Implant placement in a standardized defect $(3 \times 4 \times 5 \mathrm{~mm})$. Three titanium threaded implants $(3.75 \mathrm{~mm} \times 8 \mathrm{~mm})$ were placed. b. Random assignment of three treatment groups (from left to right: BioMend Extend ${ }^{\mathrm{TM}}$, Control and Bio-Gide ${ }^{\circledR}$ ).

- calcein green $(8 \mathrm{mg} / \mathrm{kg}, \mathrm{IM}) 2$ days after implant placement;

- xylenol orange $(60 \mathrm{mg} / \mathrm{kg}$, IV) 8 weeks after surgery;

- tetracycline $\mathrm{HCl}$ (Iomg/ $\mathrm{kg}$, IM) I2 weeks after surgery;

- alizarin red (25 mg/kg, IM) 2 days prior to sacrifice.

Therefore, these labels were administered to determine the rate and extent of osteogenesis at 2, 4, 8, I2, and I6 weeks postsurgery.

\section{Clinical reentry and histological procedure}

Animal sacrifice was carried out after 4 weeks ( $n=4$ dogs) and after I6 weeks ( $n=$ 4 dogs) with an overdose of pentobarbital $(65 \mathrm{mg} / \mathrm{kg}$, IV, to effect). At animal sacrifice, clinical reentry was performed on one quadrant at each time point to accrue clinical information and supplement histology data. Block biopsies of each quadrant including three implants and surrounding tissues were obtained, fixed in Io\% neutral buffered formalin for 4-7 days and then stored in $70 \%$ ethanol solution individually. These specimens were then dehydrated using ascending grades of alcohol, infiltrated, and embedded in methyl methacrylate (MMA) for nondecalcified sectioning (Sanderson \& Kitabayashi 1994). The orientation of the sections was transverse along the length of the implant which presented a view of the buccal defects. Three serial sections, $500 \mu \mathrm{m}$ in thickness, were taken along the long axis of the implant at the central portion of the fixture using a diamond wire saw (Well Diamond Wire Saws, Inc., Norcross, GA, USA). Each section was glued to a plastic slide (Wasatch Histo Consultants, Inc., Winnemucca, NV, USA) (Bloebaum et al. I989), ground to approximately 50-70 $\mu \mathrm{m}$ utilizing an EXAKT Micro Grinder 400 (Exakt Medical Instruments Inc., Oklahoma City, OK, USA), and polished to an optical finish. One section per each implant site was left unstained for fluorescence analysis, and the two remaining sections were stained with Sanderson's Rapid Bone Stain $^{\mathrm{TM}}$ (Surgipath Medical Industries, Richmond, IL, USA) and an acid fuchsin counterstain. Histomorphometric analyses as well as microscopic observation were performed by a calibrated, blinded examiner. For histomorphometric measurements, microscopic images were trans- 


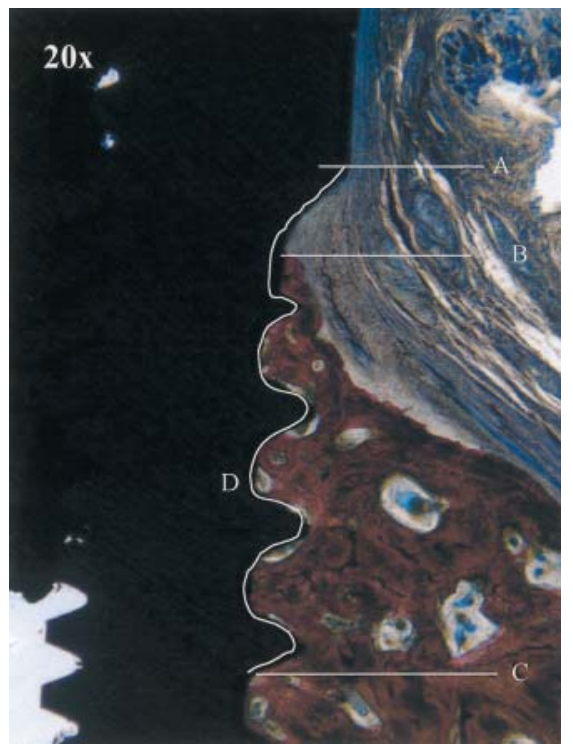

Fig. 2. Histomorphometric references (original magnification: $20 \times$, Sanderson's Rapid Bone Stain ${ }^{\mathrm{TM}} /$. IDefect Length: AC. 2-\% Linear Fill (LF): BC/AC ( $\times$ ? IOo). 3-New BIC (BIC): Sum of BIC/Total length of threads (D) ( $\times$ Ioo). 4-New Bone Fill Area (BF): Area of new bone formation. A: reference point, B: coronal extent of new bone, C: base of the defect, D: total defect length.

ferred to an IBM computer and analyzed with an image analysis software (Image-Pro Plus ${ }^{\circledR}$, The Imaging Express ${ }^{\mathrm{TM}}$, Media Cybernetics Inc., Silver Spring, MD, USA).

\section{Histomorphometry}

Parameters evaluated included:

- defect length (measured from the top of the implant neck to the base of the defect);

- percent linear fill (LF: new bone height divided by original defect length);

- percent new bone-implant contact (BIC);

- area of new bone fill (BF) (Fig. 2).

Descriptive histologic findings were also noted, such as pattern of osteogenesis, cell distributions, membrane remnants, membrane collapse, and fiber content.

\section{Statistical analysis}

For the assessment of the various treatment outcomes, two-tailed Student $t$-test was used for the mean differences within each group between 4 and I6weeks, and pairwise one-way ANOVA was used for overall mean differences between groups at each time point. For the comparison in the treatment outcomes between membrane exposure and nonexposure groups, twotailed Student $t$-test was utilized. For all statistics, the significance level used was $P<0.05$, and the data were presented as mean \pm standard error.

\section{Results}

The animals demonstrated clinical signs of healing within normal limits with no signs of infection or wound dehiscence. One implant in the I6-week group (BioMend Extend site) was lost during the healing period. Clinical reentry revealed no thread exposure in any reentered site, but the superficial layer of the defect fill resembled granulation tissue in appearance and texture. For histomorphometric analyses, the implant sites for clinical reentry were left intact, without removal of the granulation tissue. Membrane exposure was noted in nine out of 15 membrane-placed implant sites, five Bio-Gide and four BioMend Extend, at I6 weeks (one failed implant site was excluded). The exposure, when present, generally occurred with both membrane sites of the quadrant in a similar pattern.

\section{Histologic observation}

Histologically, four implants /one Bio-Gide at I6 weeks and three controls, one at 4 weeks and two at I6weeks) failed to demonstrate osseointegration, revealing fibrous encapsulation of the fixture. Additionally, one implant site in 4-week BioMend Extend group did not provide discernible sections and was excluded for histological evaluation. Therefore, the histologic and histometric analyses were carried out on a total of 42 specimens, 2 I specimens for each time period.

In all groups, 4-week specimens demonstrated woven bone formation, characterized by abundant trabecular pattern and bone marrow spaces, and the level of BIC was generally very low (Fig. 3). All membrane-treated sites demonstrated space maintenance underneath barrier membranes. Under higher magnification, the regenerated bone presented high levels of trabecular pattern, lined with osteoid seams and numerous osteoblast-like cells, and the bone trabeculae were in close contact with blood vessels, revealing active angiogenesis and osteogenesis in this early healing phase.
In contrast to the 4-week observation, more organized, dense, and mature bone was generally noted for the I6-week specimens, suggesting lamellar bone formation, and intimate contacts between the bone and implant were frequently observed (Fig. 4). There were signs of membrane disintegration, with membrane remnants visible in all membrane sites. Higher magnification demonstrated the presence of numerous osteoblasts, especially outside the border of the defect and near implant threads, suggesting continuous deposition of lamellar bone into a previously outlined bone envelope. Membrane collapse was histologically revealed in nine sites, eight membrane-exposed sites (five Bio-Gide and three BioMend Extend sites) and one nonexposed site (Bio-Gide).

At 4 weeks, newly formed bone was clearly demarcated with previously present lamellar bone by different levels of stain, while the junction between new and old bone was not clearly differentiable at I6 weeks. Fluorochrome labeling (calcein green) was used to histologically ensure or identify the junction between the old and newly formed bone (Fig. 5). In addition, fluorescence findings revealed that the pattern of osteogenesis until 4 weeks appeared as a volumetric increase of osseous tissues into defect areas, whereas there were signs of density increase in a previously occupied area in I6-week specimens.

\section{Histomorphometric analysis}

Calibration of intra- and interexaminer errors in histometric measurements resulted in $99.3 \%$ intraexaminer (TO) and $96.9 \%$ interexaminer agreement with the reference examiner (W.G.). Table I lists histometric comparison between time $/ 4$ and I6 weeks) and treatment groups. There were no statistically significant differences between groups in baseline defects, range 3.08-3.4I mm, at either time point $/ 4$ and I 6 weeks). At 4 weeks, no statistically significant differences were noted in any of the assessed parameters. The mean LF was in the range of $65-70 \%$. The mean $\mathrm{BIC}$ ranged from II \% to I9\% among groups, and BF ranged from I.I $2 \mathrm{~mm}^{2}$ to $1.46 \mathrm{~mm}^{2}$.

At I6weeks, there was a trend for greater improvements in membrane groups when compared to the control group for all parameters. There was statistically significantly more new BIC found in BioMend Extend compared to the control at 

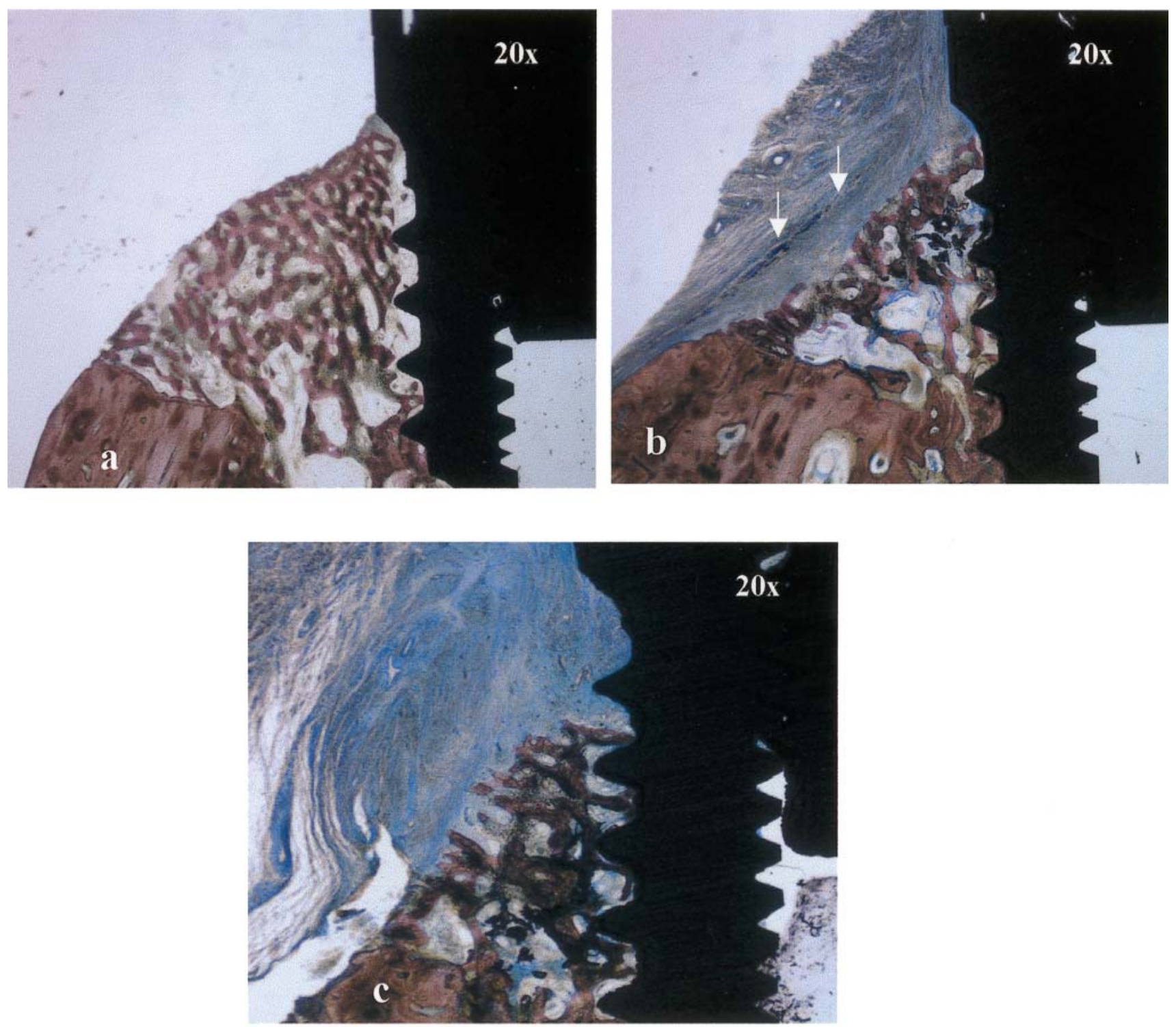

Fig. 3. Histologic observation at 4 weeks: In general, trabeculae of woven bone with abundant bone marrow spaces and low degree of BIC were observed. The newly formed bone was clearly demarcated by old bone, as demonstrated by lighter bone stain in new bone and darker stain in old bone (original magnification: $20 \times$, Sanderson's Rapid Bone Stain $\left.{ }^{\mathrm{TM}}\right)$. a - Bio-Gide ${ }^{\circledR}(n=7)$ : Trabeculae-rich woven bone formation. Soft tissues were missing due to clinical re-entry. Note the low degree of new BIC. $\mathbf{b}$ - The BioMend Extend ${ }^{\mathrm{TM}}$ collagen membranes and implants used in the study were donated by Sulzer Calcitek Dental Inc. BioMend Extend ${ }^{\mathrm{TM}}(n=7)$ : The membrane (arrows) remained intact and maintained a space for bone regeneration. $\mathbf{c}$-Control $(n=7)$ : Similar to the membrane sites, a trabecular pattern of woven bone formation is shown.

this time point $(P<0.05)$. Although there were no statistically significant differences between membrane groups and control group in LF and BF, membrane groups had approximately $60 \%$ of LF and I.3-I.9 $\mathrm{mm}^{2}$ $\mathrm{BF}$, in contrast to $45 \%$ of mean LF and $0.9 \mathrm{~mm}^{2} \mathrm{BF}$ in the control group.

Treatment outcomes between sites with membrane exposure and sites without exposure were also evaluated (Table 2). Overall, the sites with membrane exposure demonstrated significantly less mean LF
(50.9\% vs. $69.8 \%$ ) and less new BIC (31.0\% vs. $52.3 \%)(P<0.05)$. Although the mean $\mathrm{BF}$ in sites without membrane exposure was nearly twice as compared to exposed sites (I.I2 $\mathrm{mm}^{2}$ vs. $2.05 \mathrm{~mm}^{2}$ ), the difference did not reach statistical significance. Membrane exposure negatively influenced all the parameters in Bio-Gide group $(P<0.05)$; on the other hand, only new BIC was significantly influenced by membrane exposure in BioMend Extend group $(P<0.05)$. In general, membrane exposure was followed by membrane collapse (loss of space maintaining effect), resulting in significantly less bone regeneration.

\section{Discussion}

Utilizing two different collagen membranes to enhance bone augmentation in implant dehiscence defects were clinically and histologically evaluated in this canine study. Histologic analysis can be con- 

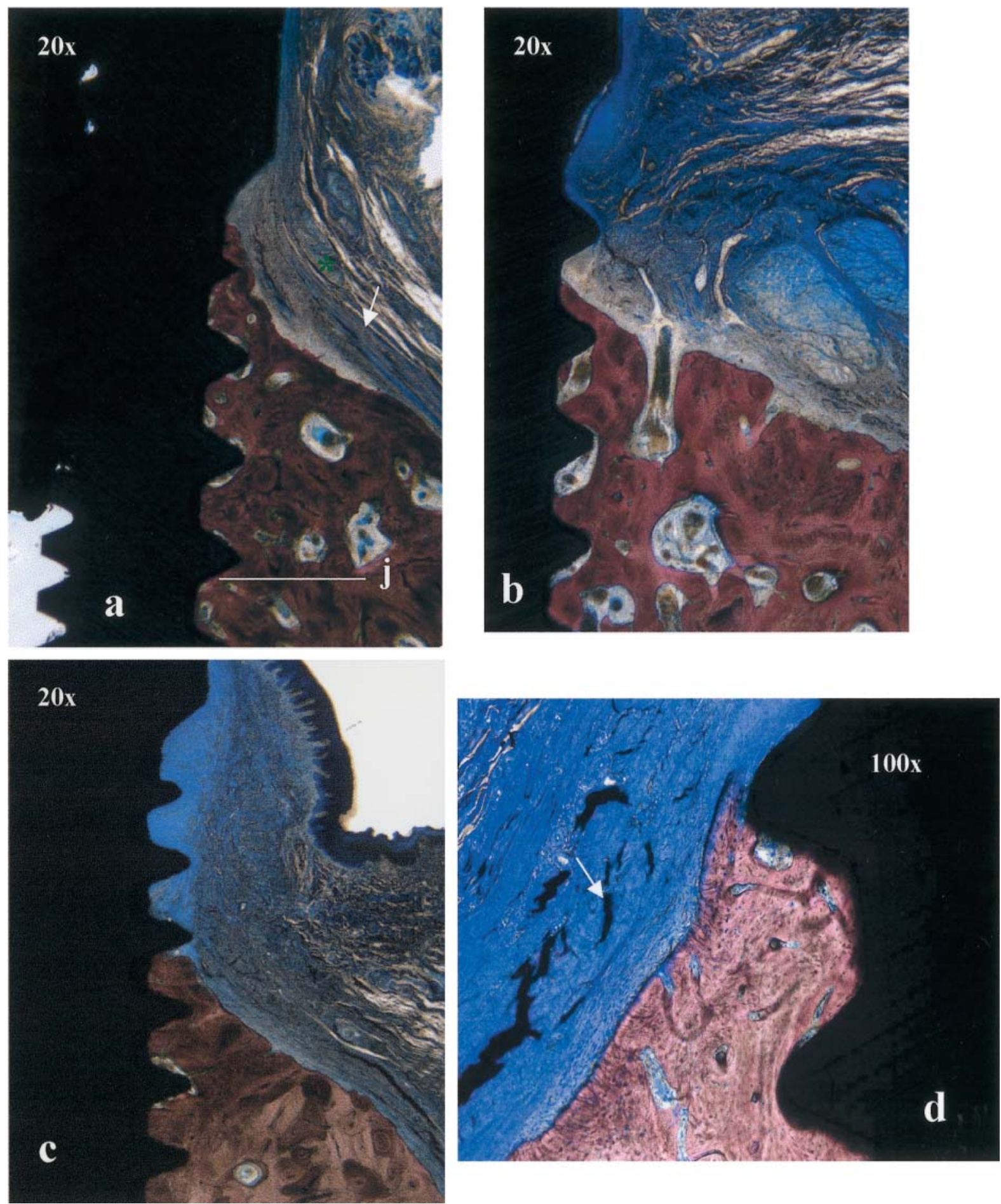

Fig. 4. Histologic observation at I6weeks: Mature, well-organized lamellar bone had been deposited in the defects. Compared to 4 weeks, new BIC levels at I6 weeks were significantly higher. Membrane groups demonstrated significantly greater linear bone fill and new bone area than control group (original magnification: $20 \times$ and Ioo $\times$, Sanderson's Rapid Bone Stain $\left.{ }^{\mathrm{TM}}\right)$. a - Bio-Gide ${ }^{\circledR}(n=8)$ : The newly formed bone was not readily distinguishable from old bone at the junction (j). The membrane (arrow) was mixed with collagen-rich fibers (asterisk), beginning to disintegrate. $\mathbf{b}-$ BioMend Extend $^{\mathrm{TM}}(n=7)$ : A space had been maintained with a barrier membrane. Evidence of new bone formation and new BIC can be noted. $\mathbf{c}$-Control $(n=6)$ : There was little evidence of space maintenance in this control specimen. $\mathbf{d}-$ Higher magnification: Membrane remnants (arrow) and numerous osteoblasts were observed especially outside border of the defect. Note the intimate contact between the implant threads and newly formed bone. 

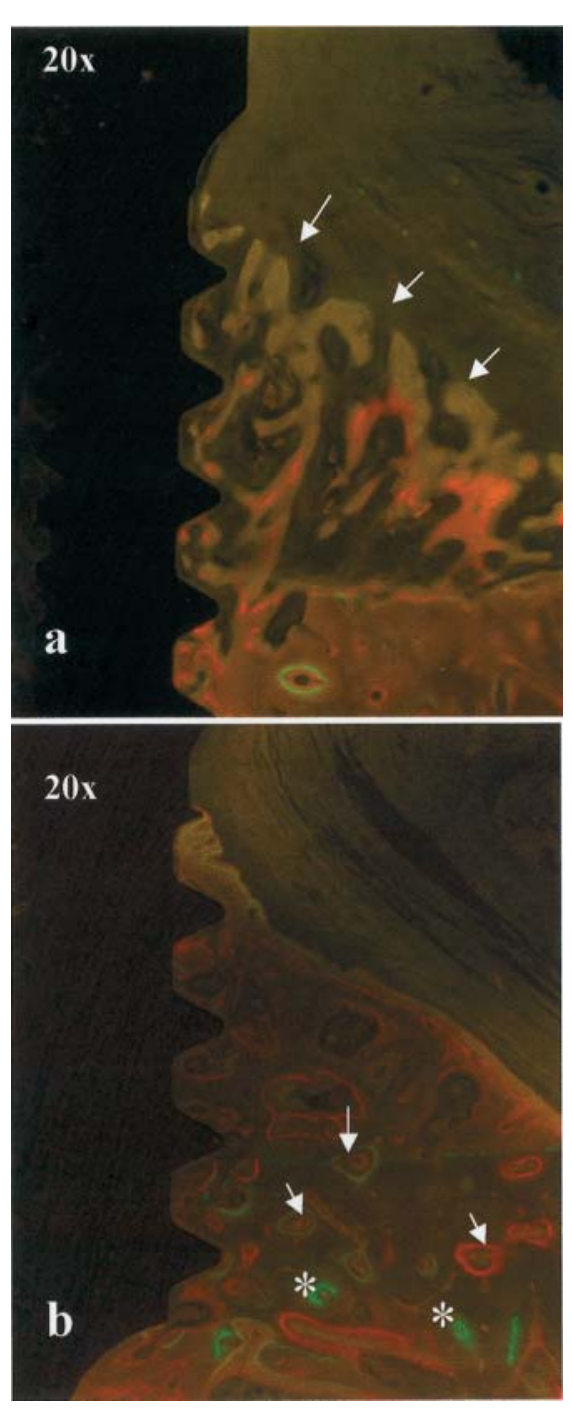

Fig. 5. Fluorescence. a-4 weeks: Fluorochrome labeling showed a timely manner of new bone formation. The junction between new bone and preexisting bone was characterized by heavy labeling with calcein green. Moreover, active bone regeneration was indicated by xylenol orange staining, which revealed a trabecular pattern, starting from the margin of old bone and underneath BioMend Extend ${ }^{\mathrm{TM}}$ membrane (arrows) (original magnification: $20 \times$, fluorescence). b- I6 weeks: Calcein green fluorochrome (asterisks) delineated the position of the junction between regenerated bone and old bone. Unlike 4-week fluorescence, this I6-week specimen showed a ring-type pattern of bone formation, indicating the presence of abundant osteons (arrows) (original magnification: $20 \times$, fluorescence).

sidered the gold standard for evaluation of bone regeneration. Due to the difficulty in obtaining histologic materials from humans, animal studies possess the advantage of attaining on standardized lesions for GBR (Dahlin et al. I988; Dahlin et al. I990; Hämmerle et al. I992; Linde et al.

Table 1. Histometric comparison between collagen barriers on bone healing at 4 and 16 weeks

\begin{tabular}{|c|c|c|c|c|}
\hline & $\begin{array}{l}\text { Defect } \\
(\mathrm{mm})\end{array}$ & $\begin{array}{l}\text { Linear fill } \\
(\%)\end{array}$ & $\begin{array}{l}\text { New BIC } \\
(\%)\end{array}$ & $\begin{array}{l}\text { Bone fill } \\
\left(\mathrm{mm}^{2}\right)\end{array}$ \\
\hline \multicolumn{5}{|c|}{ BioGide $^{\circledR}(n=8)$} \\
\hline 4 weeks & $3.08 \pm 0.10$ & $65.35 \pm 9.15$ & $16.80 \pm 2.62$ & $1.46 \pm 0.26$ \\
\hline 16 weeks & $3.29 \pm 0.12$ & $57.88 \pm 6.84$ & $34.82 \pm 4.77^{\star}$ & $1.29 \pm 0.32$ \\
\hline \multicolumn{5}{|c|}{ BioMend Extend ${ }^{\mathrm{TM}}(n=7)$} \\
\hline 4 weeks & $3.28 \pm 0.11$ & $67.59 \pm 8.79$ & $11.35 \pm 5.10$ & $1.27 \pm 0.12$ \\
\hline 16 weeks & $3.11 \pm 0.11$ & $59.17 \pm 5.36$ & $44.83 \pm 4.86^{*} \dagger$ & $1.73 \pm 0.39$ \\
\hline \multicolumn{5}{|c|}{ Control $(n=6)$} \\
\hline 4 weeks & $3.41 \pm 0.12$ & $69.45 \pm 7.92 *$ & $19.15 \pm 2.96$ & $1.12 \pm 0.14$ \\
\hline 16 weeks & $3.09 \pm 0.15$ & $44.82 \pm 5.01$ & $27.76 \pm 2.38^{*}$ & $0.88 \pm 0.19$ \\
\hline \multicolumn{5}{|c|}{$\begin{array}{l}\text { *Statistically significant difference between } 4 \text { and } 16 \text { weeks }(P<0.05) \text {. } \\
\text { †Statistically significant difference between treatment groups at } 4 \text { and } 16 \text { weeks }(P<0.05) \text {. } \\
\text { Data were presented as mean } \pm \text { ??vo } \mu \text { ? standard error. }\end{array}$} \\
\hline
\end{tabular}

I993b; Sandberg et al. I993; Schenk et al. I994; Zellin et al. I995).

The histomorphometric analysis in this study demonstrated that the placement of collagen membranes enhanced bone regeneration as determined at 16 weeks of healing, including regeneration of bone height and volume as well as bone-to-implant contact. Becker et al. (I992) studied GBR in implant dehiscence defects in dogs. Clinical reentry data at 18 weeks of the study revealed that the e-PTFE membrane alone group gained approximately $90 \%$ of LF, higher than the average LF of the membrane groups in the present study. Histometric analysis at 18 weeks in the study by Becker et al. (I992) demonstrated that new BIC was $23 \%$ for the e-PTFE alone group and $4 \mathrm{I} \%$ for e-PTFE plus growth factors group; on the other hand, the new BIC of BioMend Extend group in this study was almost $45 \%$. The differences between the two studies in LF and new BIC are likely attributed to several factors. In the Becker et al. (I992) study, the implant dehiscence defects were created around immediate extraction sockets that were longer (i.e. $5 \mathrm{~mm}$ in height). In addition, the methods of evaluating the defect resolution were different: Becker et al. (I992) used clinical measurements at reentry to assess LF whereas histometric analysis was used in the current study. It can be speculated that there would be a difference between clinical and histometric measurements in assessing degree of healing after GBR. Schliephake et al. (2000) histometrically analyzed linear bone fill (LF), comparing a polylactic acid (PLA) absorbable membrane and ePTFE membrane used for GBR around sur- gically created circumferential implant defects in dogs. The study reported that the average LF at 3 months reached approximately $45 \%$ in e-PTFE group and $40 \%$ in PLA group, lower than the present study and considerably less than Becker et al. (I992)'s clinical data. Moreover, in the current study, clinical observation at re-entry showed no thread exposure, which was different from the histometric data showing approximately $60 \%$ of LF at I6weeks. However, due to the limited sites of clinical re-entry, it was not possible to statistically compare the two measures of analysis. Third, the different types of implant surfaces used in the two studies should be considered. Machined titanium implants were used in Becker et al. (I992), while microtextured (grit-blasted) implants were placed in the present study. It has been demonstrated that the level of new BIC is significantly influenced by implant surface roughness, being greater BIC in surfaceroughened implants compared to machined titanium surfaces (Buser et al. I99I; Stentz et al. I997; Buser et al. I998; Wennerberg et al. I998; Cochran I999). Other factors for the different outcomes between the two studies may include use of different types of membrane barriers.

Histometric comparison between 4 and I6 weeks demonstrated that there was significant increase in BIC $(P<0.05)$ at I6 weeks. This finding may be explained by progressing contact osseointegration, associated with bone maturation. Interestingly, there were no significant differences between early and late healing in LF and $\mathrm{BF}$, except for a significantly lower LF at I6 weeks than 4 weeks in control group 

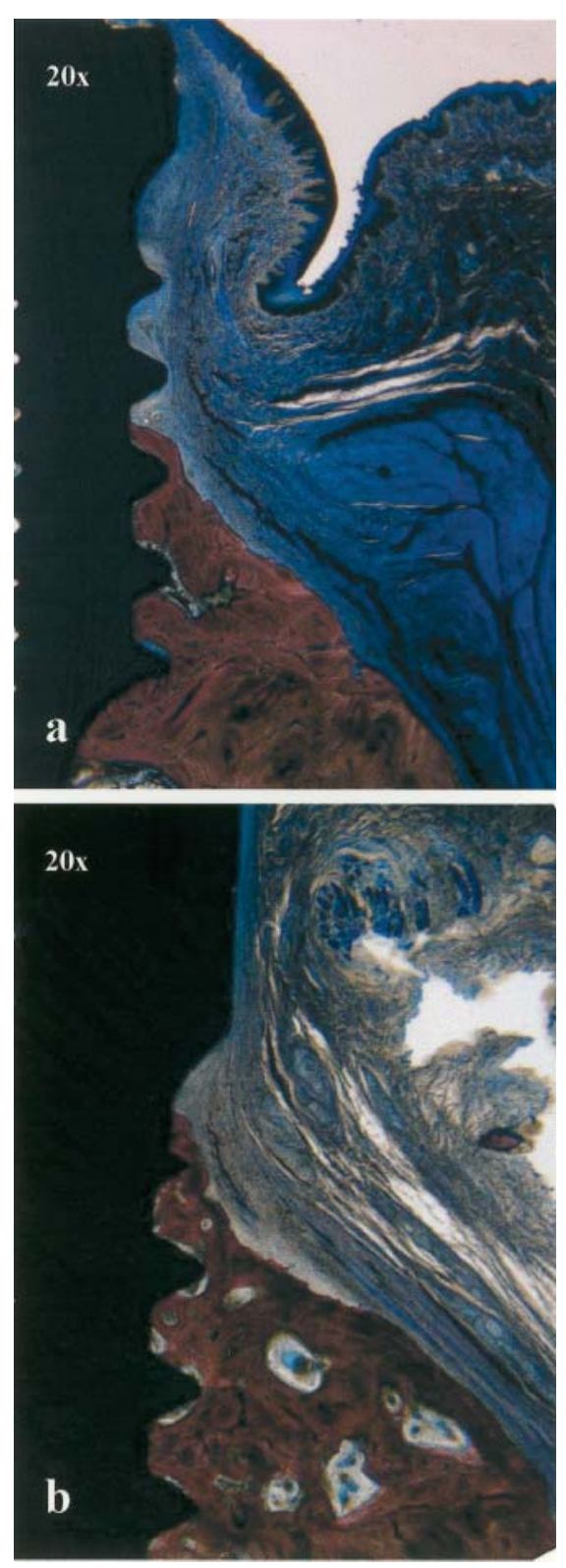

Fig. 6. Histologic appearance of membrane exposure vs. no membrane exposure at implant dehiscence defects at I6 weeks (original magnification: $20 \times$, Sanderson's Rapid Bone Stain ${ }^{\mathrm{TM}}$ ). a - Site with membrane exposure $(n=9)$ : The soft tissue and membrane were collapsed, resulting in less bone regeneration. b-Site without membrane exposure $(n=6)$ : The structural integrity of the barrier membrane remained undisturbed, with space maintenance for new bone formation

$(P<0.05)$. This is mainly attributed to several inherent problems of the current study. The small sample size in association with biologic variability, manifested by considerably high standard deviation, might have influenced the lack of statisti-

Table 2. Influence of membrane exposure on bone regeneration 16 weeks postsurgery

\begin{tabular}{|c|c|c|c|c|}
\hline & $\begin{array}{l}\text { Defect } \\
(\mathrm{mm})\end{array}$ & $\begin{array}{l}\text { Linear fill } \\
(\%)\end{array}$ & $\begin{array}{l}\text { New BIC } \\
(\%)\end{array}$ & $\begin{array}{l}\text { Bone fill } \\
\left(\mathrm{mm}^{2}\right)\end{array}$ \\
\hline Exposure $(n=9)$ & $3.27 \pm 0.12$ & $50.92 \pm 5.01$ & $30.95 \pm 0.03$ & $1.12 \pm 0.26$ \\
\hline No exposure $(n=6)$ & $3.11 \pm 0.11$ & $69.82 \pm 4.95^{*}$ & $52.31 \pm 0.03^{*}$ & $2.05 \pm 0.40$ \\
\hline \multicolumn{5}{|l|}{ BioGide ${ }^{\circledR}$} \\
\hline Exposure $(n=5)$ & $3.39 \pm 0.24$ & $47.23 \pm 9.54$ & $27.20 \pm 7.31$ & $0.80 \pm 0.55$ \\
\hline No exposure $(n=3)$ & $3.11 \pm 0.27$ & $75.63 \pm 9.93^{*}$ & $47.52 \pm 3.31$ * & $2.10 \pm 0.46$ * \\
\hline \multicolumn{5}{|l|}{ BioMend Extend ${ }^{\mathrm{TM}}$} \\
\hline Exposure $(n=4)$ & $3.12 \pm 0.29$ & $55.54 \pm 13.43$ & $35.63 \pm 2.39$ & $1.53 \pm 0.65$ \\
\hline No exposure $(n=3)$ & $3.10 \pm 0.14$ & $64.01 \pm 7.32$ & $57.10 \pm 6.69 *$ & $2.01 \pm 1.06$ \\
\hline
\end{tabular}

cal significance. In addition, membrane (or space) collapse and flap exposure might also have negatively influenced the outcome of the late stage of bone healing, resulting in less LF at I6 weeks compared to at 4 weeks. However, under the limit of the findings of this study, it is implied that as bone matures from early phase to late stage of healing, BIC and density increase, without significant increases in bone height or bone fill. There could be a question raised as to whether or not the pattern of bone maturation involves bone volume reduction accompanied by density increase.

Significant differences in treatment outcomes between sites with membrane exposure and nonexposed sites may impose a great clinical relevance. The sites with no membrane exposure demonstrated significantly greater $\mathrm{LF}, \mathrm{BIC}$, and $\mathrm{BF}$, supported by other experimental and clinical studies (Nowzari \& Slots I995; Gotfredsen et al. I993; Lekholm et al. I993; Becker et al. I994; Gher et al. I994; Simion et al. I994a; Kohal et al. I998; Parma-Benfenati et al. I999). Machtei (200I) recently performed a meta-analysis and reported that membrane exposure results in significantly less bone formation in GBR procedure, and when compared to GTR procedures, the negative effects on treatment outcomes were more detrimental, indicating that primary closure of healing wound in GBR procedures is a major factor for the success of new bone formation in dental implants. However, only two GBR studies were used for this analysis. Kohal et al. (I998) demonstrated that early membrane exposure resulted in significantly less BIC, expressed as torque required to remove implants, compared to nonexposed implant sites in a canine model. Possible reasons for the high membrane exposure rate in this study included a cage-chewing behavior of dogs (Henry et al. I997) and remaining flap tension. Since the membrane exposure, when present, was observed in entire quadrant, including control site, the exposure would have been more likely induced by animal behavior (or remaining flap tension) rather than membrane materials.

Histologic observations at I6 weeks demonstrated loss of membrane integrity even in the sites without membrane exposure, and a pattern of membrane collapse in most of the exposed sites (eight out of nine) in which less regeneration was obtained. This indicates that the treatment outcomes were mainly dependent upon the presence or absence of membrane exposure and/or space collapse, not significantly influenced by membrane resorption time. Owens \& Yukna (200I) recently evaluated the pattern of collagen membrane resorption, comparing three different collagen membranes, Bio-Gide, AlloDerm ${ }^{\circledR}$ porcine-derived (LifeCell, Branchburg, N), USA), and AlloDerm ${ }^{\circledR}$ human-derived (LifeCell, Branchburg, NJ, USA), in dogs. They observed that all membranes had near-complete degradation by 3 months and were completely absent by 4 months. Crigger et al. (I996) reported that highly crosslinked collagen membranes resulted in significantly less attachment gain compared to weak cross-linked, rapid resorbing collagen membranes in periodontal defects in dogs.

Several limitations were associated with the present study. This study is an animal study which provides a model to the human situation. Second, the small sample size in association with large biologic vari- 
ability might have affected the results of statistical significance. Third, GBR was employed in surgically created defects (acute wounds) rather than naturally occurring chronic lesions. The size of the defects used in the study might not be of and represent critical-size kinetic defects to measure the effects of GBR temporally. Finally, the negative influence of the high membrane exposure rate and space collapse noted in the present study could have been reduced by fixating membranes or adding space-maintaining materials, such as bone grafts or metal pins. Carpio et al. (2000) reported that membrane fixation at GBR surgery resulted in significantly less postoperative complications with greater bone regeneration, as compared to no membrane fixation. In addition, a histologic study in implant dehiscence defects in monkeys demonstrated that a combined use of barrier membranes and anorganic bovine bone substitutes (Bio-Oss) had greater gains in bone height and width at 6 months, compared to other groups, including membrane alone, Bio-Oss alone, or control (Hämmerle et al. I998). The rationale for the use of bone substitutes in GBR may include: (I) space creation/maintenance, (2) acting as a scaffold for angiogenesis and perivascular cells such as osteoprogenitor cells, and (3) providing a carrier for bone growth factors (Hämmerle 1999).

Under the limits of the present study, it was concluded that GBR treatment using collagen membranes, either Bio-Gide or BioMend Extend, may enhance bone regeneration, including bone height gain, new bone-to-implant contact, and bone fill, manifested at a later stage of healing. Space maintenance and prevention of membrane exposure during healing could be crucial factors for the success of GBR.

\footnotetext{
Acknowledgments This study was supported by the University of Michigan, Periodontal Graduate Student Research Fund. The authors acknowledge Sulzer Dental Inc. for their provision of BioMend Extend ${ }^{\mathrm{TM}}$ collagen membranes and implants used in the study. Also, we acknowledge Cathy Mayton for her excellent work in histologic preparation.

Disclaimers: The authors do not have any financial interests, either directly or indirectly, in the products listed in the study.
}

\section{Résumé}

La régénération osseuse guidée (GBR) provient du principe de la régénération tissulaire guidée (GTR) et a été utilisée pour reconstruire des sites ayant des lésions osseuses associées aux implants dentaires. Pour la GBR, des membranes collagène dégradables ont été utilisées mais l'information scientifique de l'utilisation de membranes collagène pour GBR est limitée. Cette étude a eu pour but de comparer cliniquement et histomorphométriquement deux membranes collagène (Bio-Guide ${ }^{\circledR}$ et BioMend Extend $^{\mathrm{TM}}$ ) pour le traitement de lésions de déhiscence au niveau d'implants chez huit chiens bâtards. Les lésions de déhiscence autour des implants ont été créées chirurgicalement dans des rebords édentés à la suite du placement de trois implants endo-osseux bilatéralement au niveau de la mandibule. Chaque lésion de déhiscence implantaire était répartie au hasard dans un des trois groupes de traitement : I) contrôle (pas de membrane), 2 | barrière collagène de derme de porc (Bio-Guide®), ou 3 | barrière collagène de tendon bovin (BioMend Extend ${ }^{\mathrm{TM}}$ ). Quatre chiens ont été tués après quatre semaines et quatre autres après seize semaines. L'analyse histomorphométrique comprenait le pourcentage de remplissage osseux linéaire (LF), de nouveau contact os-implant (BIC) et l'aire du nouveau remplissage osseux (BF). Les résultats de l'étude n'ont révélé aucune différence significative parmi les groupes pour aucun paramètre après quatre semaines. Cependant après seize semaines, il y avait davantage de LF, BIC et BF dans les groupes traités par membrane que dans les contrôles. Les lésions traitées par BioMend Extend $^{\mathrm{TM}} \mathrm{s}^{\prime}$ accompagnaient davantage de BIC que les contrôles $(\mathrm{p}<0,05)$. BIC à seize semaines était significativement plus important qu'à quatre semaines $(\mathrm{p}<0,05)$. Neuf des quinze sites examinés avaient la membrane exposée dans la cavitée buccale aboutissant à moins de LF et BIC que dans les sites sans membrane exposée $(\mathrm{p}<0,05)$. Les résultats de cette étude ont montré que I le traitement GBR avec des membranes collagène peut significativement augmenter la régénération osseuse après seize semaines de guérison 2) le maintien de l'espace et le maintien du recouvrement par la membrane étaient les deux facteurs les plus importants.

\section{Zusammenfassung}

Die gesteuerte Knochenregeneration (GBR) wurde aus dem Konzept der gesteuerten Geweberegeneration entwickelt und wurde zur Rekonstruktion von Knochendefekten im Zusammenhang mit dentalen Implantaten eingesetzt. Für die GBR werden immer häufiger Kollagenmembranen eingesetzt. Wissenschaftliche Informationen über die Verwendung von Kollagenmembranen zur GBR sind nur beschränkt vorhanden. Das Ziel dieser Studie war es, zwei Kollagenmembranen, Bio-Gide ${ }^{\circledR}$ und BioMend Extend $\circledast$, klinisch und histomorphometrisch bei der Behandlung von Dehiszenzdefekten an 8 nicht reinrassigen Hunden zu vergleichen. Die Dehiszenzdefekte wurden im zahnosen Kiefer chirurgisch geschaffen, daraufhin wurden 3 enossale Implantate beidseits im Unterkiefer eingesetzt. Jeder Implantatdehiszenzdefekt wurde zufällig einer der drei Behandlungsgruppen zugeteilt: (I) Kontrollgruppe (keine Membran), (2) Kollagenbarriere aus Schweinehaut (Bio-Gide ${ }^{\circledR}$ ) oder (3) Kollagenbarriere aus Rindersehnen (BioMend Extend $\circledast$ ). Die Hunde wurden 4 und I6 Wochen nach der Behandlung geopfert (jeweils 4 Tiere). Die histomorphometrische Analyse bestand aus folgenden Parametern: \% lineare Auffüllung mit Knochen (LF), neuer Implantat-Knochenkontakt (BIC) und Auffüllung mit neuem Knochen (BF). Die Resultate der Studie zeigten nach 4 Wochen für keinen der Parameter signifikante Unterschiede zwischen den Gruppen. Jedoch konnten nach I6 Wochen mehr LF, BIC und BF für die membranbehandelten Gruppen als für die Kontrollgruppe registriert werden. Defekte, welche mit BioMend Extend $\circledast^{\circledR}$ behandelt wurden, zeigten zu diesem Zeitpunkt signifikant mehr BC als die Kontrollgruppe $(\mathrm{p}<0.05)$. BIC nach I6 Wochen war signifikant grösser als BIC nach 4 Wochen $(\mathrm{p}<0.05)$. Bei 9 von I5 untersuchten Stellen kam es zu Membranexpositionen, was im Vergleich zu Stellen ohne Membranexposition zu signifikant weniger LF und BIC führte $(\mathrm{p}<0.05)$. Die Resultate dieser Studie zeigen, dass (I) die GBR-Behandlung mit Kollagenmembranen die Knochenregeneration signifikant erhöhen kann, was sich aber erst in einer späten Phase der Heilung (I6 Wochen) manifestiert ; und dass (2) die Erhaltung eines Hohlraumes und die Bedeckung der Membran die zwei wichtigsten Faktoren bei der GBR mit bioresorbierbaren Kollagenmembranen darstellen.

\section{Resumen}

La regeneración ósea guiada (GBR) evolucionó del concepto de regeneración tisular guiada (GTR) y ha sido usada para reconstruir lugares con deficiencias óseas asociadas con implantes dentales. Para la GBR, el uso de membranas reabsorbibles de colágeno se ha ido incrementando, pero en la actualidad, la información científica sobre el uso de las membranas de colágeno para GBR es limitada. Este estudio tuvo la intención de comparar clínica e histomorfometricamente dos membranas de colágeno, BioGide $^{\circledR}$ y BioMendExtend ${ }^{\mathrm{TM}}$, para el tratamiento de defectos de dehiscencia en implantes en 8 perros mongrel. Los defectos de dehiscencia se crearon quirúrgicamente en crestas edéntulas, seguida de la colocación de 3 implantes endoóseos bilateralmente en la mandíbula. Cada defecto de dehiscencia fue asignado aleatoriamente a uno de los e grupos de tratamiento: (I) Control (sin membrana) (2) Barrera de colágeno de dermis porcina (Bio-Gide $\left.{ }^{\circledR}\right)$, o $(3)$ Barrera de colágeno de tendón bovino (BioMendExtend ${ }^{\mathrm{TM}}$ ). Los perros se sacrificaron a las 4 y I6 semanas (4 cada una) tras el tratamiento. El análisis histomorfométrico incluyó \% lineal de relleno óseo (LF), contacto nuevo hueso a implante (BIC) y área de relleno de nuevo hueso $(\mathrm{BF})$. Los resultados del estudio no revelaron diferencias significativas entre los grupos para ningún parámetro a las 4 semanas. Sin embargo, a las I6 semanas, se observó una mayor LF, BIC, y BF en los grupos tratados con membranas que en los controles. Los defectos tratados con BioMendExtend ${ }^{\mathrm{TM}}$ demostraron un mayor BIC que el control $(p<0.05)$ en este punto. El BIC a las I6 semanas fue significativamente mayor que el BIC a las 4 semanas $(\mathrm{p}<0.05)$. La exposición de la membrana ocurrió en 9 de los I 5 lugares examinados, resultando en un menor LF y BIC que los lugares sin exposición de la membrana $(\mathrm{p}<0.05)$. Los resultados de este estudio indican que: (I) El tratamiento de GBR con membranas de colágeno puede estimular significativamente la regeneración ósea, manifestada en estados tardios (I6 semanas) de cicatrización; y (2) El mantenimiento del espacio y la cobertura de la membrana fueron los dos factores mas importantes que afectaron la GBR usando membranas de colágeno biorreabsorbibles. 
贸旨

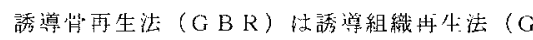
$T R$ ）から念朋され、菌科インブラントに関連し て骨裂開のある再建部位に做いられてきている。 GBRに扔いて吸収性江ラーダン・メンブレンの 使用が增版てきているが、兒在まで G B R に拉 けるコラーダン・メンブレンり使川に関する科学 的情報山限られている。本研究は、8炕の雑種犬 においてインプラント裂開の治滰について医椺的

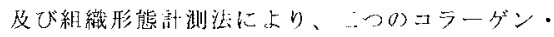
メンブレン Bio・Gider と BioMend lixtend

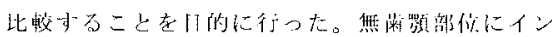
ナ゙ラントの梨開型父提を外科的に作成し、次に3

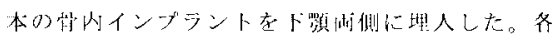

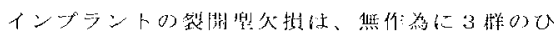

\section{References}

Balshi, T.J., Hernandez, R.E., Cutler, R.H. \& Hertzog, C.F. (1991) Treatment of osseous defects using Vicryl mesh (polyglactin 910) and the Branemark implant: a case report. International Journal of Oral and Maxillofacial Implants 6: 87-9I.

Becker, W., Dahlin, C., Becker, B., Lekholm, U., van Steenberghe, D., Higuchi, K. \& Kultie, C. (1994) The use of e-PTFE membranes for bone promotion around titanium implants placed into extraction sockets: a prospective multicenter study. International Journal of Oral and Maxillofacial Implants 9: 3I-40.

Becker, W., Lynch, S.E., Lekholm, U., Becker, B.E., Caffesse, R., Donath, K. \& Sanchez, R. (I992) A comparison of ePTFE membranes alone or in combination with platelet-derived growth factors and insulin-like growth factor-I or demineralized freeze-dried bone in promoting bone formation around immediate extraction socket implants. Journal of Periodontology 63: 929940.

Bloebaum, R.D., Sanderson, C., McCarvill, S. \& Campbell, P. (1989) Plastic slides in the preparation of implant and tissue for interface analysis. Journal of $\mathrm{Hi}$ stotechnology I2: 307-310.

Blumenthal, N.M. (I988) The use of collagen membranes to guide regeneration of new connective tissue attachment in dogs. Journal of Periodontology 59: 830-836.

Boyne, P.J. (I969) Restoration of osseous defects in maxillofacial causalities. Journal of American Dental Association 78: 767-776.

Buser, D., Nydegger, T., Hirt, H.P., Cochran, D.L. \& Nolte, L.P. (I998) Removal torque of titanium implants in the maxilla of miniature pigs. International Journal of Oral and Maxillofacial Implants I3: 6I I-6I9.

Buser, D., Schenk, R.K., Steinemann, S., Fiorellini, J.P., Fox, C.H. \& Stich, H. (I99I) Influence of surface characteristics on bone integration of titanium implants: a histomorphometric study in miniature pigs. Journal of Biomedical Materials Research 25: 889-902.

Carpio, L., Loza, J., Lynch, S. \& Genco, R. (2000) Guided bone regeneration around endosseous implants with anorganic bovine bone mineral. A randomized controlled trial comparing bioabsorbable versus non-absorbable barriers. Journal of Periodontology 7I: 1743I749.

Cochran, D.L. (1999) A comparison of endosseous dental implant surfaces. Journal of Periodontology. 70: $1523-$ I539.

Crigger, M., Bogle, G.C., Garrett, S. \& Gantes, B.G. (I996) Repair following treatment of circumferential periodontal defects in dogs with collagen and expanded po-
とつに报り分けた；才捈わち1）奴照(メンダレ ン存し，2）豚真发のヨラーダン・メンブレン (Bio-Gide(R) と 3 ) 4:腱のコラーダン・バりけ

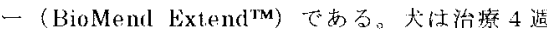
問後及ぴ1.6週閒後に(备 4 匹才゙つ)居殺した。組

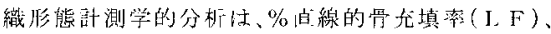
新尘骨とインブラントの挍能出稹（ＢＩＣ）及び

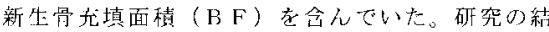
来法、4 週問後にはどのパラメーターも群間の有 意差在分さなかった。しかし16 週問後には L F、 B I C及びBFは、メンブレンで治㙩した群の方 が刘照群より多かった。BioMend Extend ${ }^{\mathrm{TM}}$ で治

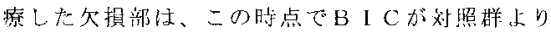

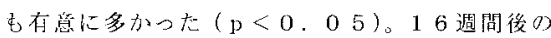

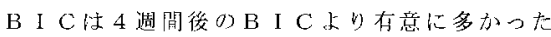

$(p<0.05)$ ○メフフレンの露山は梌榃した 1 5部位のうち9部位で起こり、メンブレンの露山 汃起こらなかった部位に比べ、 L F と B I C が有 意に低下した $(\mathrm{p}<0 \cdot 05)$ 。本研究の結界は、 1) コラーグン・メンブレンによるGBRの給䋨 江、背再生老有意に促谁し、その效果は治澺期開 の後期（16 週間後）に発揮される山能性がある; そして2）空隙の稚持とメンブレンの被要は、生 体吸收性コラーグン・メンブレンを朋いた G BR に影響を及ぼ最も乘紧な2 要素であった。 キーリード:誘障骨舟生法、バリヤーメンー゙レン 生休吸收性、コラーダン・メンブレン、歯科イン プラント、メンブレンの露出、インブラントの裂 開型众提 lytetrafluoroethylene barrier membranes. Journal of Periodontology 67: 403-4I3.

Dahlin, C., Andersson, L. \& Linde, A. (I99I) Bone augmentation at fenestrated implants by an osteopromotive membrane technique: a controlled clinical study. Clinical Oral Implants Research 2: I59-165.

Dahlin, C., Gottlow, J., Linde, A. \& Nyman, S. (I990) Healing of maxillary and mandibular bone defects using a membrane technique: An experimental study in monkeys. Scandinavian Journal of Plastic, Reconstructive and Hand Surgery 24: I3-19.

Dahlin, C., Linde, A., Gottlow, J. \& Nyman, S. (I988) Healing of bone defects by guided bone regeneration. Plastic Reconstructive Surgery 8I: 672-676.

Fritz, M.E., Jeffcoat, M.K., Reddy, M., Koth, D., Braswell, L.D., Malmquist, J. \& Lemons, J. (2000) Guided bone regeneration of large mandibular defects in a primate model. Journal of Periodontology 7I: I484-I489.

Fugazzotto, P.A., Shanaman, R., Manos, T. \& Shectman, R. (I997) Guided bone regeneration around titanium implants: Report of the treatment of I, 503 sites with clinical reentries. International Journal of Periodontics and Restorative Dentistry 17: 292-299.

Gher, M.E., Quintero, G., Assad, D., Monaco, E. \& Richardson, A.C. (I994) Bone grafting and guided bone regeneration for immediate dental implants in humans. Journal of Periodontology 65: 88I-89I.

Giannobile, W.V., Ryan, S., Shih, M.S., Su, D.L., Kaplan, P.L. \& Chan, T.C. (I998) Recombinant human osteogenic protein-I (OP-I) stimulates periodontal wound healing in class III furcation defects. Journal of Periodontology 69: I29-I 37 .

Gotfredsen, K., Nimb, L., Buser, D. \& Hiørting-Hansen, E. (I993) Evaluation of guided bone regeneration around implants placed into fresh extraction sockets: An experimental study in dogs. Journal of Oral and Maxillofacial Surgery 5r: 879-884.

Hämmerle, C.H. (1999) Membranes and bone substitutes in guided bone regeneration. In: Lang, N.P., Karring, T. \& Lindhe, J., eds. Proceedings of the 3 rd European Workshop on Periodontology, p. 483. Berlin: Quintessence Publishing Co.

Hämmerle, C.H., Chiantella, G.C., Karring, T. \& Lang, N.P. (I998) The effect of a deproteinized bovine bone mineral on bone regeneration around titanium dental implants. Clinical Oral Implants Research 9: I5 I-I62. Hämmerle, C.H., Schmid, J., Olah, A.J. \& Lang, N.P. (I992) Osseous healing of experimentally created defects in the calvaria of rabbits using guided bone regeneration: a pilot study. Clinical Oral Implants Research 3: I44-I47.
Henry, P.J., Tan, A.E., Leavy, I., Johansson, C.B. \& Albrektsson, T. (1997) Tissue regeneration in bony defects adjacent to immediately loaded titanium implants placed into extraction sockets: a study in dogs. International Journal of Oral and Maxillofacial Implants I2: 758-766.

Hermann, J.S. \& Buser, D. (I996) Guided bone regeneration for dental implants. Current Opinion in Periodontology 3: I68-I77.

Hürzeler, M.B., Kohal, R.J., Naghshbandi, J., Mota, L.F., Conradt, I., Hutmacher, D. \& Caffesse, R.G. (I998) Evaluation of a new bioresorbable barrier to facilitate guided bone regeneration around exposed implant threads: An experimental study in the monkey. International Journal of Oral and Maxillofacial Surgery 4: 3I5-320.

Hutmacher, D., Hürzeler, M.B. \& Schliephake, H. (I996) A review of material properties of biodegradable and bioresorbable polymers and devices for GTR and GBR applications. International Journal of Oral and Maxillofacial Implants II: 667-678.

Kohal, R.J., Mellas, P., Hürzeler, M.B., Trejo, P.M., Morrison, E. \& Caffesse, R.G. (I998) The effects of guided bone regeneration and grafting on implants placed into immediate extraction sockets. An experimental study in dogs. Journal of Periodontology 69: 927-937.

Lam, R.V. (1960) Contour changes of the alveolar process following extraction. Journal of Prosthetic Dentistry Io: $25-32$.

Lekholm, U., Becker, W., Dahlin, C., Becker, B., Donath, K. \& Morrison, E. (1993) The role of early versus late removal of GTAM membranes on bone formation at oral implants placed into immediate extraction sockets: An experimental study in dogs. Clinical Oral Implants Research 4: I2 I-I29.

Lekholm, U. \& Zarb, G.A. (I985) Osseointegration in clinical dentistry. In: Branemark, P.-I, Zarb, G.A. \& Albrektson, T., eds. Patient Selection and Preparation, p. 199. Chicago: Quintessence Publications Co.

Linde, A., Alberius, P., Dahlin, C., Bjurstam, K. \& Sundin, Y. (I993a) Osteopromotion: a soft tissue exclusion principle using a membrane for bone healing and bone neogenisis. Journal of Periodontology 64: I I I 6-I I 28.

Linde, A., Thoren, C., Dahlin, C. \& Sandberg, E. (r993b) Creation of new bone by an osteopromotive membrane technique: An experimental study in rats. Journal of Oral and Maxillofacial Surgery 51: 892-897.

Lundgren, D., Sennerby, L., Falk, H., Friberg, B. \& Nyman, S. (1994) The use of a new bioabsorbable barrier for guided bone regeneration in connection with im- 
plant installation: Case reports. Clinical Oral Implants Research 5: I77-I84.

Machtei, E. (200I) The effect of membrane exposure on the outcome of regenerative procedures in humans: a meta-analysis. Journal of Periodontology 72: 5I 2-5I6.

Mayfield, L., Nobreus, N., Attstrom, R. \& Linde, A. (I997) Guided bone regeneration in dental implant treatment using a bioabsorbable membrane. Clinical Oral Implants Research 8: IO-I7.

Mellonig, J.T. \& Nevins, M. (I995) Guided bone regeneration of bone defects associated with implants: An evidence-based outcome assessment. International Journal of Periodontics and Restorative Dentistry $\mathbf{5} 5$ : I68-I 85 .

Nowzari, H. \& Slots, J. (I995) Microbiologic and clinical study of polytetrafluoroethylene membrane for guided bone regeneration around implants. International Journal of Oral and Maxillofacial Surgery 10: 67-72.

Owens, K.W. \& Yukna, R.A. (200I) Collagen membrane resorption in dogs: a comparative study. Implant Dentistry Io: 48-58.

Parma-Benfenati, S., Tinti, C., Albrektsson, T. \& Johansson, C. (I999) Histological evaluation of guided vertical ridge augmentation around dental implants in humans. International Journal of Periodontics and Restorative Dentistry I9: 425-437.

Peleg, M., Chaushu, G., Blinder, D. \& Taicher, S. (I999) Use of lyodura for bone augmentation of osseous defects around dental implants. Journal of Periodontology 70: 853-860.

Postlethwaite, A.E., Seyer, J.M. \& Kang, A.H. (I978) Chemotactic attraction of human fibroblast to type I, II, and III collagens and collagen derived peptides. Proceedings of the National Academy of Sciences of the United States of America 75: 870-875.

Sandberg, E., Dahlin, C. \& Linde, A. (I993) Bone regenera- tion by the osteopromotion technique using bioabsorbable membranes: An experimental study in rats. Journal of Oral and Maxillofacial Surgery 5I: I IO6-I I I4.

Sanderson, C. \& Kitabayashi, L.R. (I994) Parallel experiences of two different laboratories with the initiator Perkadox I6 for polymerization of methylmethacrylate. Journal of Histotechnology I7: 343-348.

Schenk, R., Buser, D., Harwick, W.R. \& Dahlin, C. (I994) Healing pattern of bone regeneration in membrane-protected defects: a histologic study in the canine mandible. International Journal of Oral and Maxillofacial Implants 9: 13-29.

Schliephake, H., Dard, M., Planck, H., Hierlemann, H. \& Jakob, A. (2000) Guided bone regeneration around endosseous implants using a resorbable membrane vs. a PTFE membrane. Clinical Oral Implants Research II: 230-24I.

Sevor, J. \& Meffert, R. (I992) Placement of implants into fresh extraction sites using a resorbable collagen membrane: Case reports. Practical Periodontics and Aesthetic Dentistry 4: 35-4I.

Sevor, J., Meffert, R. \& Cassingham, R. (I993) Regeneration of dehisced alveolar bone adjacent to endosseous dental implants utilizing a resorbable collagen membrane: Clinical and histologic results. International Journal of Periodontics and Restorative Dentistry I3: 7I-83.

Simion, M., Baldoni, M., Rossi, P. \& Zaffe, D. (I994a) A comparative study of the effectiveness of ePTFE membranes with and without early exposure during the healing period. International Journal of Periodontics and Restorative Dentistry I4: I67-I80.

Simion, M., Dahlin, C., Trisi, P. \& Piattelli, A. (I994b) Qualitative and quantitative comparative study on different filling materials used in bone tissue regeneration: a controlled clinical study. International Journal of Periodontics and Restorative Dentistry I4: I99-2 I5. Stentz, W.C., Mealey, B.L., Gunsolley, J.C. \& Waldrop, T.C. (I997) Effects of guided bone regeneration around commercially pure titanium and hydroxyapatitecoated dental implants. II. Histologic analysis. Journal of Periodontology 68: 933-949.

Wang, H.L. \& MacNeil, R.L. (I998) Guided tissue regeneration. Absorbable barriers. Dental Clinics of North America. 42: 505-522.

Wang, H.L., O'Neal, R.B., Thomas, C.L., Shyr, Y. \& MacNeil, R.L. (I994) Evaluation of an absorbable collagen membrane in treating class II furcation defects. Journal of Periodontology 65: 1029-I036.

Wennerberg, A., Hallgren, C., Johansson, C. \& Danelli, S. (1998) A histomorphometric evaluation of screwshaped implants each prepared with two surface roughness. Clinical Oral Implants Research 9: I I-I9.

Yukna, C.N. \& Yukna, R.A. (I996) Multi-center evaluation of bioabsorbable collagen membrane for guided tissue regeneration in human class II furcations. Journal of Periodontology 67: 650-657.

Zablotsky, M., Meffert, R., Caudill, R. \& Evans, G. (I99I) Histological and clinical comparisons of guided tissue regeneration on dehisced hydroxylapatite-coated and titanium endosseous implant surfaces: a pilot study. International Journal of Oral and Maxillofacial Implants 6: 294-303.

Zellin, G., Gritli-Linde, A. \& Linde, A. (I995) Healing of mandibular defects with different biodegradable and non-biodegradable membranes: An experimental study in rats. Biomaterials I6: 60I-609.

Zitzmann, N.U., Naef, R. \& Scharer, P. (I997) Resorbable versus non-resorbable membranes in combination with Bio-Oss for guided bone regeneration. International Journal of Oral and Maxillofacial Implants 12: 844852. 